【論文】

UDC : 624. 012. $45: 624.073 .75$
日本建築学会構造系論文報告集 第·417 号・1990 年 11 月

Journal of Struct. Constr. Engng, AIJ, No.417, Nov., 1990

\title{
フラットスラブのせん断力に関する研究 SHEARING FORCES ANALYSIS OF FLAT SLAB STRUCTURE
}

\author{
松井源 吾*, 田中 聡** \\ Gengo MATSUI and Satoshi TANAKA
}

\begin{abstract}
This paper discusses an analysis of the shearing forces around the drop panel of a flat slab structure:

In this study, several shapes of the drop panel are investigated in case of an uniformly distrib. uted load.

The analytical solutions of the shearing forces are derived from the analogy between the equation of a slope of the membrane and the equation of a shearing forces of a plate.

The results of the shearing forces among the several shapes are obtained by the experiments in membrane.
\end{abstract}

Keywords : Flat slab, shearing forces, Moire method, drop panel

\section{まえがき}

フラットスラブ構造に関する研究では，曲げに関して は多くの研究があるが；せん断に関する理論的研究はほ とんどなされていない。倉庫のように積載荷重が大きい 場合，また，柱間隔が大きい場合などでは，支板付近で のせん断力は大きくなる。支板周辺のせん断力の分布は， 支板の形で大きく変化する。本論文は，支板の形を種々 変化させた場合の, 支板周辺の最大せん断力の変化を求 めることを目的とする。

一般に等分布荷重をうける板の二方向の曲げモーメン 卜の和は，等分布荷重をうける薄膜のたわみと相似であ る。板のせん断力は，この二方向の曲げモーメントの微 分であるので，膜のたわみの傾斜を求めることにより， 板のせん断力を求めることができる。

実験は，ゴムの薄膜に，直交方向に膜ののびを一定と する方法で一様張力を加えた後, 膜に空気圧を加えて, これを等分布荷重とする。次に，その等高線をモアレ法 で求め，その傾斜から板のせん断力を求めている。また， 別に四辺支持正方形の膜のたわみを測定し，一縞の高さ について検定している。

なお，支板の形が円形の場合は，板の円板解を利用し， 正方形の場合は，さらに等角写像を利用して，膜実験の 妥当性を証明した。

\section{1. 板のせん断力と薄膜の相似}

板の $x, y$ 方向の曲げモーメントは，それぞれ

$$
\begin{aligned}
& M_{x}=-D\left(\frac{\partial^{2} w}{\partial x^{2}}+\nu \frac{\partial^{2} w}{\partial y^{2}}\right) \\
& M_{y}=-D\left(\frac{\partial^{2} w}{\partial y^{2}}+\nu \frac{\partial^{2} w}{\partial x^{2}}\right) \\
& \text { v：ポアソン比 }
\end{aligned}
$$

で示されるリ。

これらの直交する曲げモーメントの和を $M$ とする $\varepsilon$,

$$
M=M_{x}+M_{y}=-D(1+\nu)\left(\frac{\partial^{2} w}{\partial x^{2}}+\frac{\partial^{2} w}{\partial y^{2}}\right)
$$

となる。板のたわみの微分方程式は2,

$$
\frac{\partial^{4} w}{\partial x^{4}}+2 \frac{\partial^{4} w}{\partial x^{2} \partial y^{2}}+\frac{\partial^{4} w}{\partial y^{4}}=\frac{q}{D}
$$

ただし， $q$ : 等分布荷重

この式に前式の $M$ を代入すると,

$$
\frac{\partial^{2} M}{\partial x^{2}}+\frac{\partial^{2} M}{\partial y^{2}}=-(1+\nu) q
$$

となる。これを極座標に変換すると，

$$
\frac{\partial^{2} M}{\partial r^{2}}+\frac{1}{r} \frac{\partial M}{\partial r}+\frac{1}{r^{2}} \frac{\partial^{2} M}{\partial \theta^{2}}=-(1+\nu) q
$$

板のせん断力は,
* 早稲田大学 教授・工博

** 早稲田大学 大学院生・工修
Professor, Department of Architecture; Waseda Univ., D. Eng. Graduate Student, Department of Architecture, Waseda Univ., M. Eng. 


$$
\begin{aligned}
& Q_{x}=-D \frac{\partial}{\partial x}\left(\frac{\partial^{2} w}{\partial x^{2}}+\frac{\partial^{2} w}{\partial y^{2}}\right) \\
& Q_{y}=-D \frac{\partial}{\partial y}\left(\frac{\partial^{2} w}{\partial x^{2}}+\frac{\partial^{2} w}{\partial y^{2}}\right)
\end{aligned}
$$

である ${ }^{3 !}$ 。 $x$ 軸之 $\alpha$ の角度をなす方向を $n$ とすると，

$$
Q_{n}=Q_{x} \cos \alpha+Q_{y} \sin \alpha
$$

$$
=-D \frac{\partial}{\partial n}\left(\frac{\partial^{2} w}{\partial x^{2}}+\frac{\partial^{2} w}{\partial y^{2}}\right)
$$

$\therefore Q_{n}=\frac{1}{1+\nu} \frac{\partial M}{\partial n}$

一方，一様な張力 $S$ で張られた，等分布荷重 $q$ をう

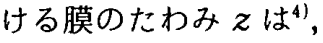

$$
\frac{\partial^{2} z}{\partial x^{2}}+\frac{\partial^{2} z}{\partial y^{2}}=-\frac{q}{S}
$$

この（4）式は，（1）式と相似である。すなわち

$$
(1+\nu)=1 / S
$$

とおけば，曲げモーメントの和 $(M)$ は，膜のたわみ $(z)$ と同じになる。（３）式より，曲げモーメントの和 $(M)$ を微分したものが板のせん断力であるから，膜のたわみ の傾斜がこれに対応する。

2. 曲げモーメントの和と膜のたわみ

\section{(a) 支板円形の場合}

次式を（2）式の解とする。

$$
M=-\frac{(1+\nu)}{4} q a^{2}\left\{C_{1}+C_{2} \log \left(\frac{a}{r}\right)+\left(\frac{r}{a}\right)^{2}\right\}
$$

ただし， $C_{1}, C_{2}$ : 定数

$r=a$ にて, $M=0$ より $C_{1}=-1$

$r=b$ にて, $\frac{d M}{d r}=0$ より $C_{2}=2 \frac{b^{2}}{a^{2}}$

ゆえに

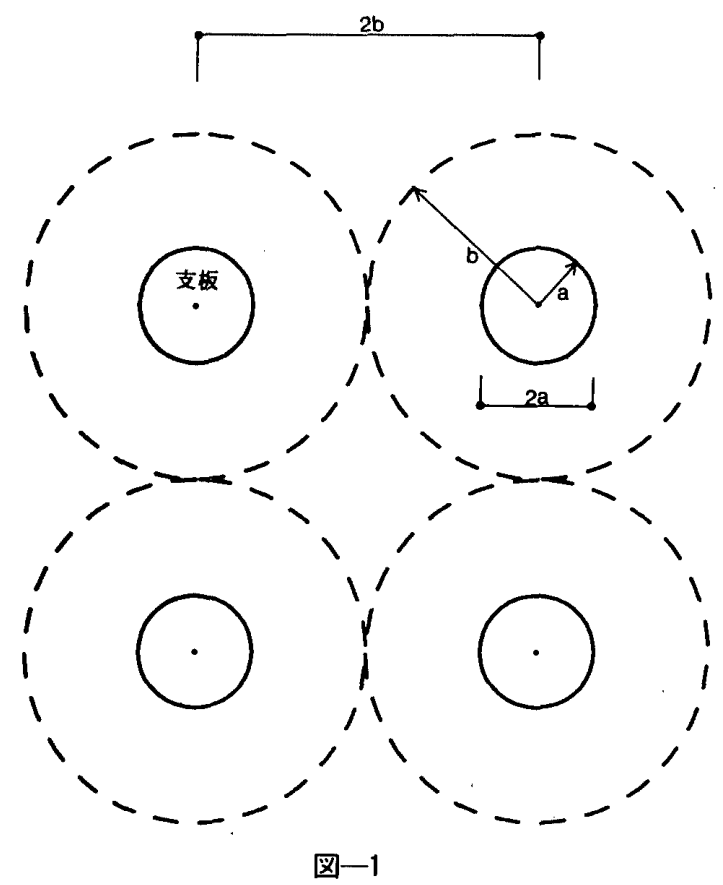

$$
M=-\frac{(1+\nu)}{4} q a^{2}\left\{2 \frac{b^{2}}{a^{2}} \log \left(\frac{a}{r}\right)+\left(\frac{r}{a}\right)^{2}--1\right\}
$$

$b=2.5 a$ とすると, 支板付近は写真一 1 の膜実験の $E$ アレ写真のように，等高線は同心円群となる。图一2 は,

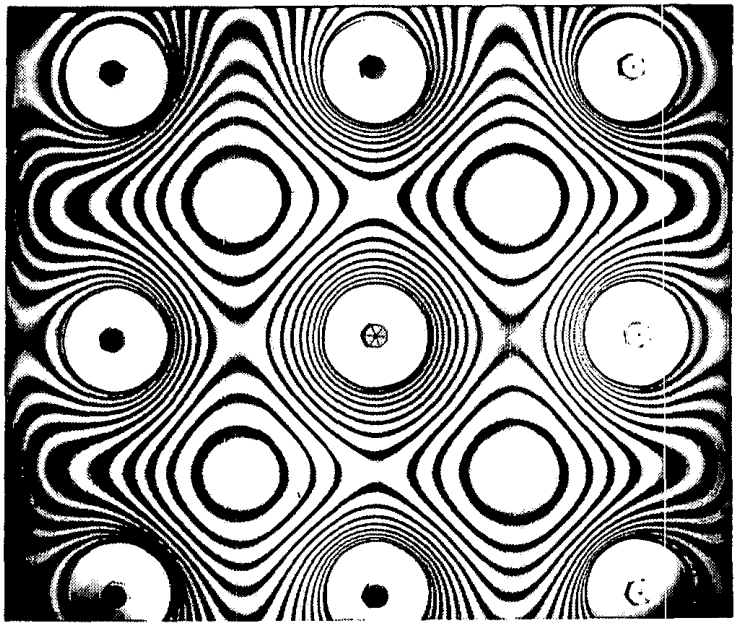

写真一1 円形支板の場合のモアレ写真

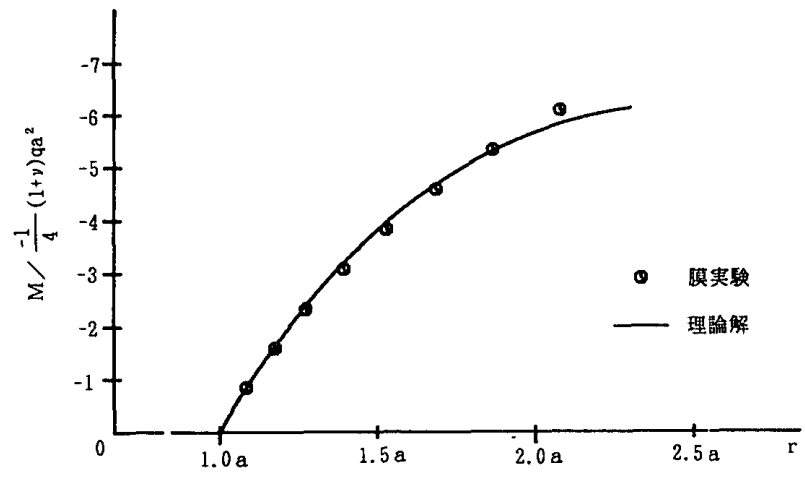

图一2 円形支板の場合の $M\left(\theta=0^{\circ}\right)$

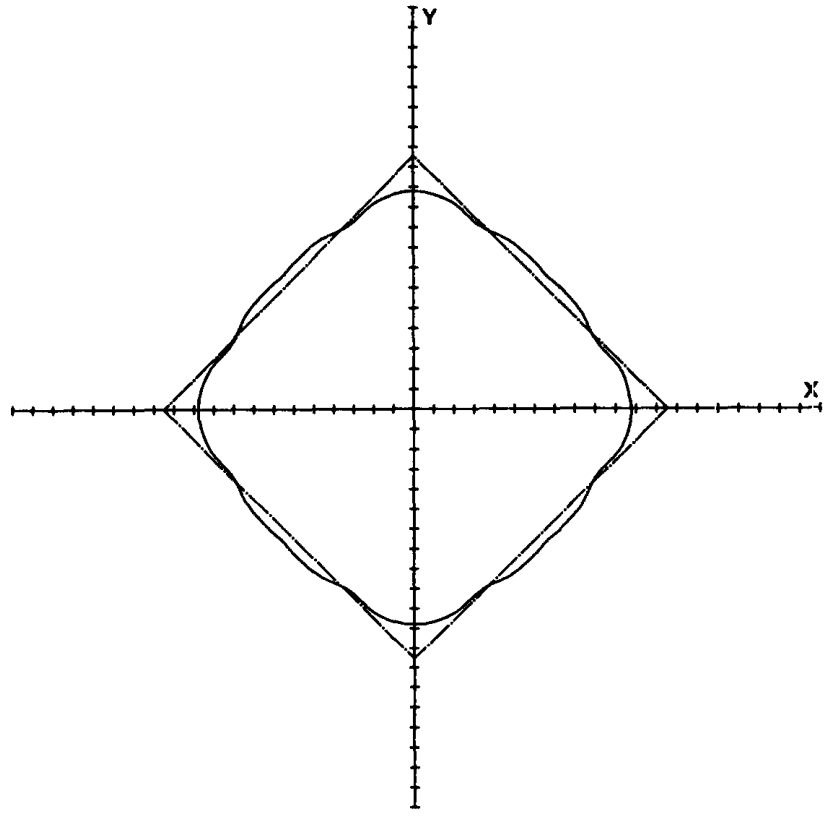

図-3 
上式の計算値にこの実験值をプロットしたものである。 支板からかなり離れたところまで，よく一致している。

（b）支板が隅をまるめた正方形の場合

この場合は, 円の場合に

$$
C_{n}\left(\frac{r}{a}\right)^{-n} \cos n \theta
$$

なる項を加える。これは複素関数

$$
C_{n} Z^{-n}
$$

の㬰部であるので，この項を加えても，（2）式は满足 される。よって

$$
\begin{aligned}
& M=-\frac{(1+\nu)}{4} q a^{2}\left\{2 \frac{b^{2}}{a^{2}} \log \left(\frac{a}{r}\right)+\left(\frac{r}{a}\right)^{2}-1\right. \\
&\left.+\sum C_{n}\left(\frac{r}{a}\right)^{-n} \cos n \theta\right\} \cdots \cdots \cdots \cdots \cdots \cdots( \\
& \text { ここに } C_{4}=3 / 4, \quad C_{8}=1 / 3, \quad C_{12}=1 / 7
\end{aligned}
$$

とすると， $M=0$ は隅をまるめた正方形に近似した形が 得られる（図一3の実線）。

写真一 2 は,これに似た形の正方形の膜実験による等 高線である。なお，支板の面積は円の場合と同じにして いる。（6）式によって計算して得られる等高線は，図 -4のように実験と似ており，支板から離れると等高線

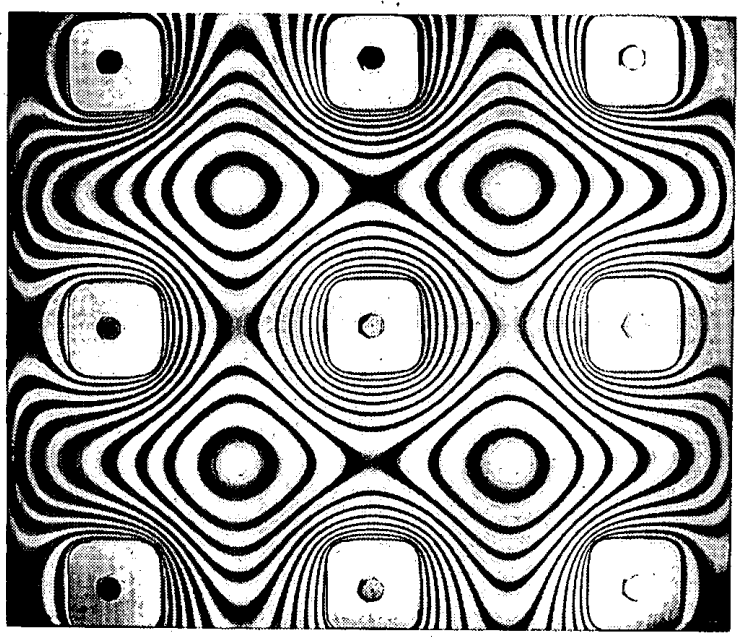

写真一2 隅をまるめた正方形支板の場合のモアレ写真

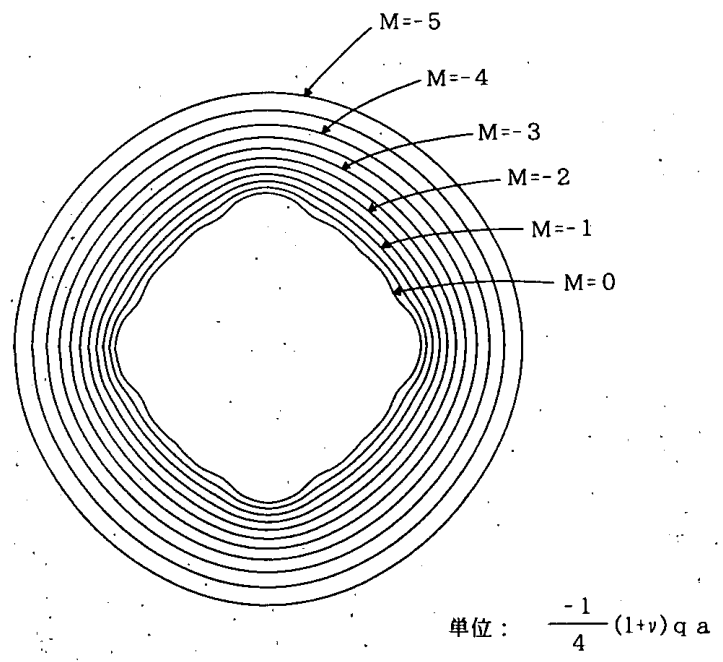

図-4
は円に近づく。図一 5 は， $\dot{x}$ 軸上の $M$ の值の計算值に 実験値をプロットしたもので，よく一致している。

これらの結果は，膜実験のたわみが，曲げモーメント の和 $(M)$ とよく一致することを示している。

\section{3. せん断力とその最大值}

曲げモーメントの和 $(M)$ の微分は，（3）式によりせ ん断力を表すので, 種々の支板の形状について膜実験を 行い, その膜のたわみの傾斜からせん断力を求める。

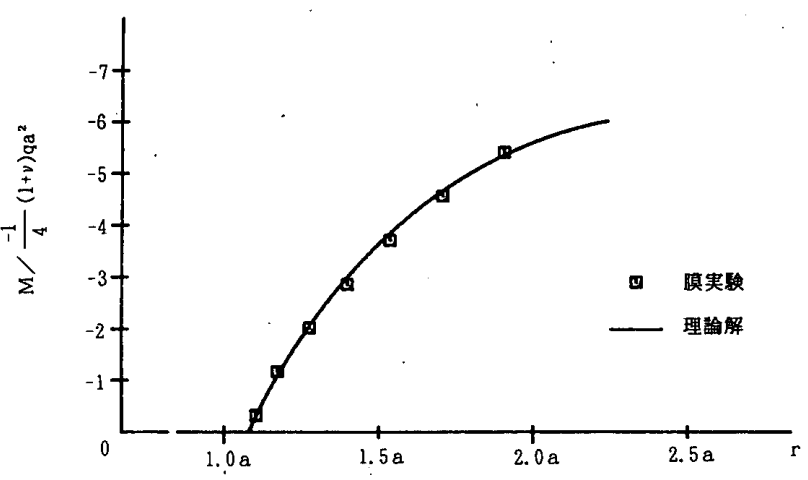

図一5 隅をまるめた正方形支板の場合の $M\left(\theta=0^{\circ}\right)$

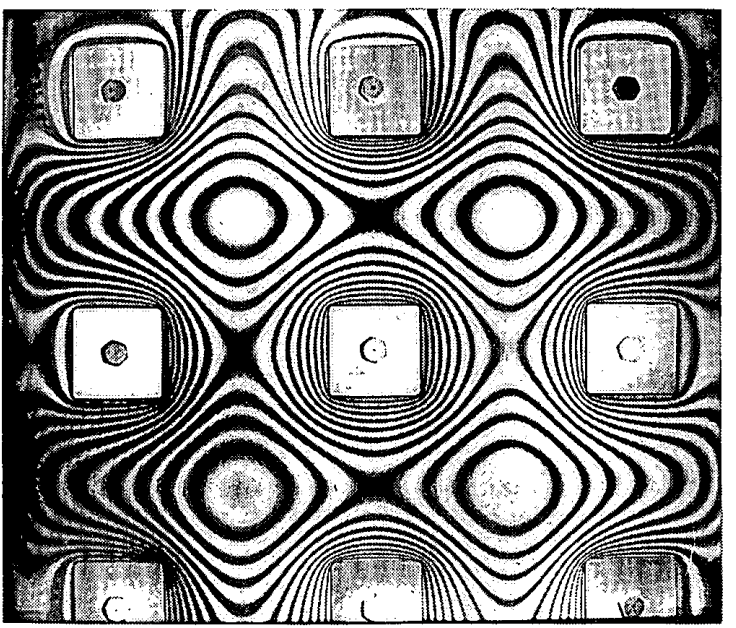

写真一3 正方形支板の場合のモアレ写真

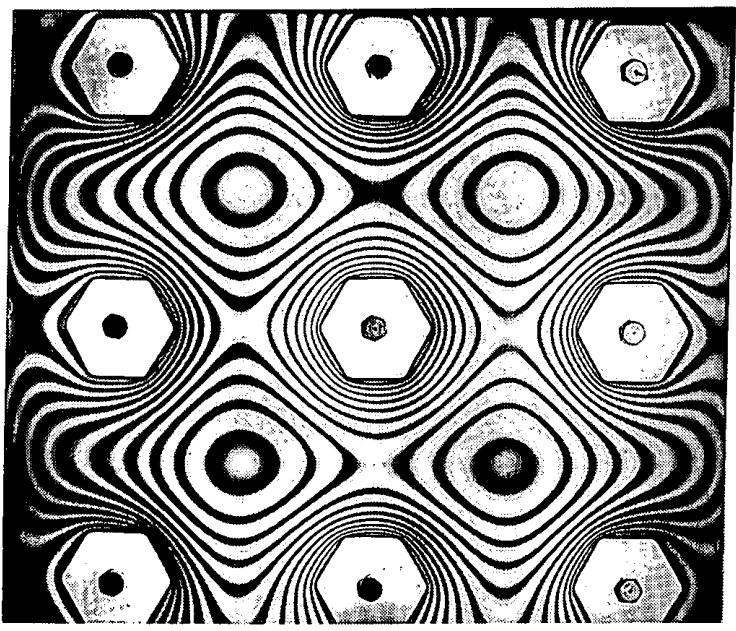

写真一4 正六角形支板の場合のモアレ写真 


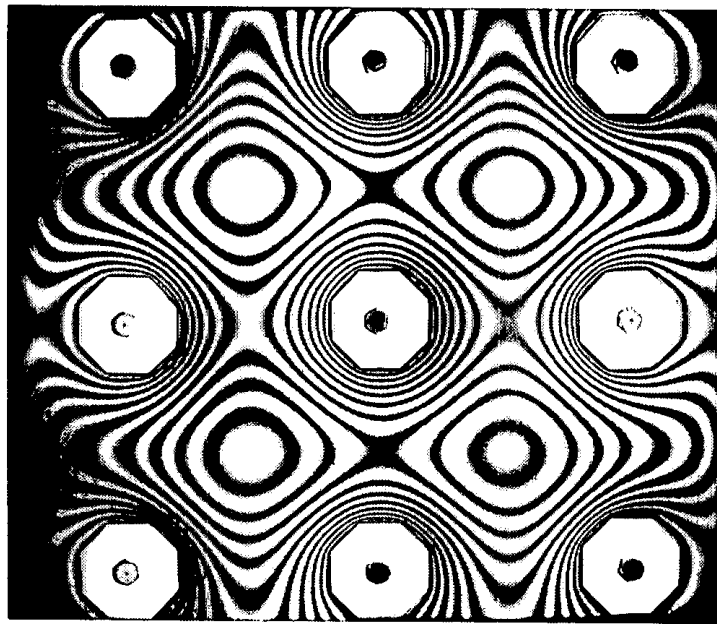

写真一5 正八角形支板の場合のモアレ写真
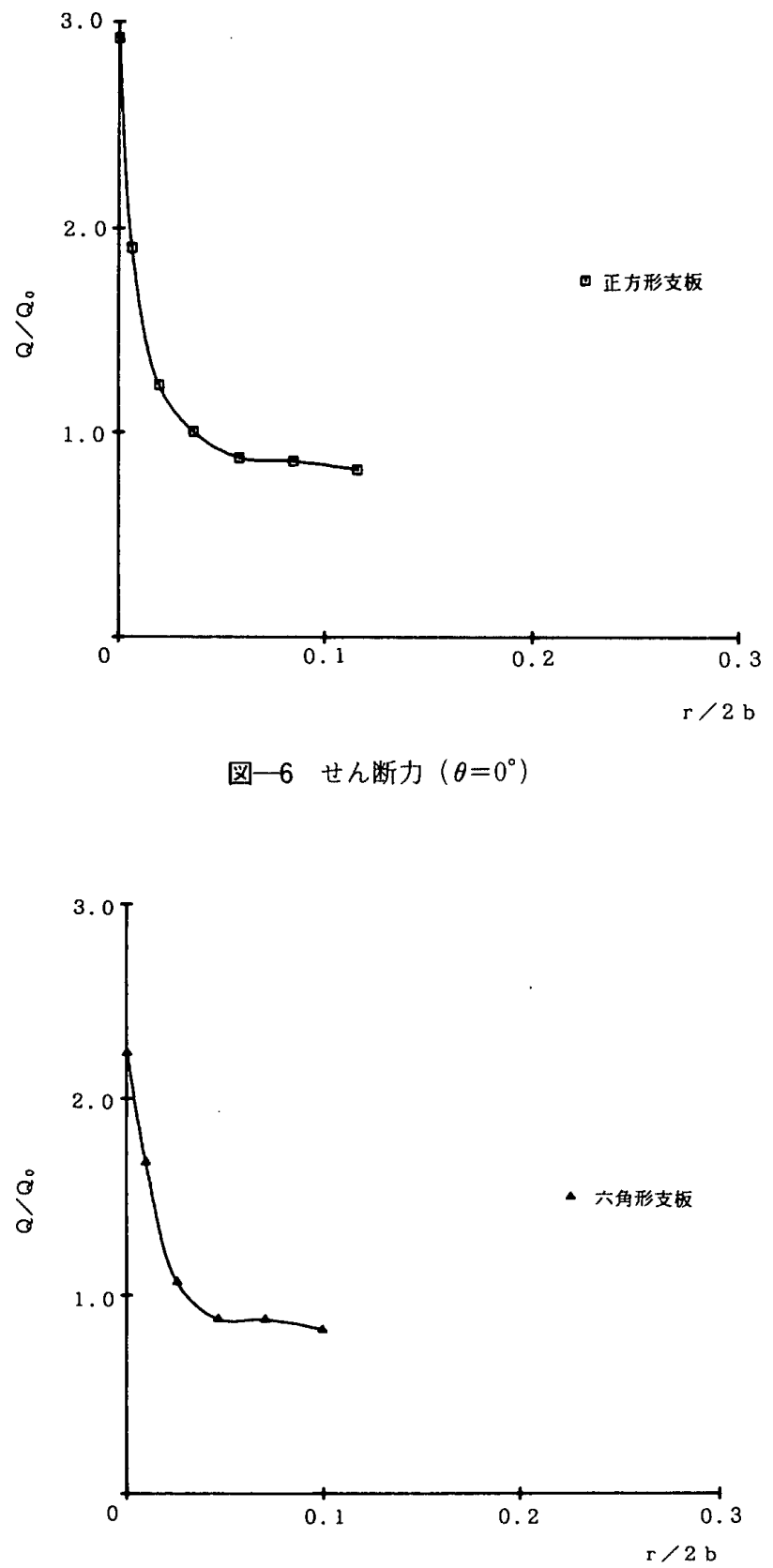

图一7 せん断力 $\left(\theta=0^{\circ}\right)$

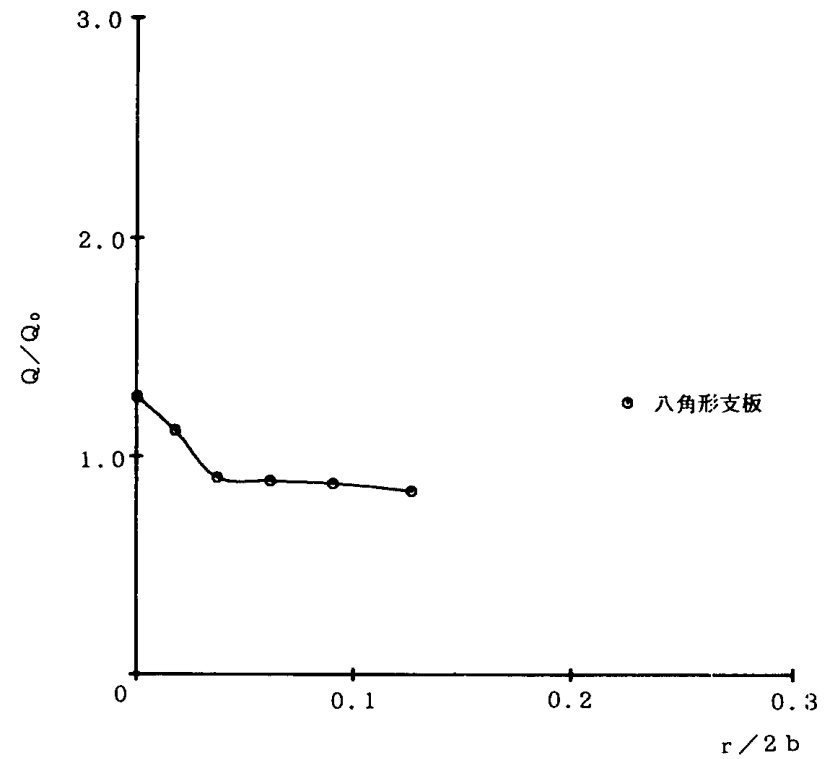

図一8 せん断力 $\left(\theta=0^{\circ}\right)$

すなわち,

$$
Q_{r}=\frac{1}{1+\nu} \frac{\partial M}{\partial r}
$$

基準として，円形支板の場合の支板位置でのせん断方 を用いる。

写真一 $3,4,5$ は，支板が正方形, 正六角形, 正八解 形の場合の，モアレ法による膜実験の等高線で占る。い ずれも，支板を離れると等高線は円となる。

せん断力最大となる隅の方向について，膜のたわみの 傾斜からせん断力を求めたものが，図一6,7，8である。

$Q_{0}$ は，円形の場合の支板值置でのせん断力で，これ を基準としている。いずれも支板を離れると減少してい る。最大せん断力は, 正方形で, 円形の場合の 2.9 倍, 正六角形が 2.2 倍, 正八角形が 1.3 倍である。

計算例として, $2 b=900 \mathrm{~cm}, a=180 \mathrm{~cm}, q=2800$ $\mathrm{kg} / \mathrm{m}^{2}$ ， スラブ厚 $30 \mathrm{~cm}$ とすると，せん断応力度は, 円 形では $6.7 \mathrm{~kg} / \mathrm{cm}^{2}$ となり，C 210 の長期の許容せん盺

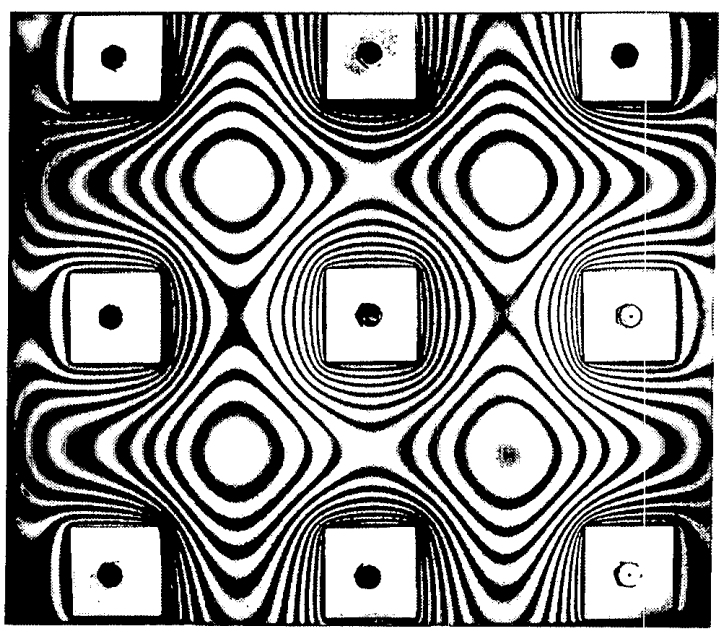

写真一 6 先の尖った正方形支板の場合のモアレ写真 
応力度は $7 \mathrm{~kg} / \mathrm{cm}^{2}$ なので，許容応力内におさまるが， 正八角形では $8.5 \mathrm{~kg} / \mathrm{cm}^{2}$, 正六角形では $14.7 \mathrm{~kg} / \mathrm{cm}^{2}$, 正方形では $19.4 \mathrm{~kg} / \mathrm{cm}^{2}$ となり，円形以外はいずれも許 容応力を超えてしまう。

以上，膜実験による，フラットスラブ構造における支 板付近のせん断力について考察したが，板のせん断力を 膜のたわみの傾斜から求めるこの方法は，一般的に応用 範囲が広いと考えられる。

\section{付 記}

正方形の膜実験（写真一3）では，隅にわずかなまる みを持たせているが，まるみがないものを写真一 6 に示
す。隅の局部をのぞいて，ほとんぞ写真一 3 と同じであ る。

注

1) Timoshenko, Woinowsky-Krieger 「Theory of Plates and Shells」, McGraw-Hill, p. 81 (101) 式, 1959

2) 同 p. $82(103)$ 式

3) 同 p. $82(106),(107)$ 式

4) Timoshenko, Goodier TTheory of Elasticity」McGrawHill, p. 304 (159) 式, 1970

（1990 年 4 月 4 日原稿受理，1990 年 9 月 8 日採用決定） 